This is an author produced version of a paper published in International Journal of Geriatric Psychiatry. This paper has been peer-reviewed but does not include the final publisher proof-corrections or journal pagination.

Citation for the published paper:

Bjorkelund, Karin Bjorkman and Larsson, Sylvia and Gustafson, Lars and Andersson, Edith.

"The Organic Brain Syndrome (OBS) scale: a systematic review." International Journal of Geriatric Psychiatry, 2006, Issue: Jan 27. http://dx.doi.org/10.1002/gps.1449

Access to the published version may require journal subscription.

Published with permission from: Wiley InterScience 


\section{The Organic Brain Syndrome (OBS) Scale: A Systematic Review}

Karin Björkman Björkelund, RN, Doct. Stud. ${ }^{1,2}$, Sylvia Larsson, RN, $\mathrm{PhD}^{2}$, Lars Gustafson, $\mathrm{MD}, \mathrm{PhD}$, Prof. ${ }^{3}$, Edith Andersson, $\mathrm{RN}, \mathrm{PhD}^{2}$

From the ${ }^{1}$ Department of Anesthesiology and Intensive care, Clinical Sciences, Lund, Lund University, P.O. Box 117, SE-221 00, Lund, Sweden; the ${ }^{2}$ Department of Health Sciences, Lund University, P.O. Box 157, SE-221 00, Lund, Sweden and the

${ }^{3}$ Department of Psychogeriatrics, Clinical Sciences, Lund, Lund University, P.O. Box 117, SE-221 00, Lund, Sweden

Correspondence and reprint requests:

Doct. Stud. Karin Björkman Björkelund

Department of Health Sciences,

Lund University,

P.O. Box 157,

SE-221 00, Lund, Sweden.

Phone: +46-46-2221854. Fax: +46-46-2221824.

E-mail: karin.bjorkman_bjorkelund@med.lu.se 


\section{ABSTRACT}

Background/Objective: The Organic Brain Syndrome (OBS) Scale was developed to determine elderly patients' disturbances of awareness and orientation as to time, place and own identity, and assessment of various emotional and behavioural symptoms appearing in delirium, dementia and other organic mental diseases. The aim of the study was to examine the OBS scale, using the eight criteria and guidelines formulated by the Scientific Advisory Committee of the Medical Outcomes Trust (SAC), and to investigate its relevance and suitability for use in various clinical settings.

Method: Systematic search and analysis of papers (30) on the OBS scale were carried out using the criteria suggested by the SAC.

Results: The OBS Scale in many aspects satisfies the requirements suggested by the SAC: conceptual and measurement model, reliability, validity, responsiveness, interpretability, respondent and administrative burden, alternative forms of administration, and cultural and language adaptations, but there is a need for additional evaluation, especially with regard to different forms of reliability, and the translation and adaptation to other languages.

Conclusions: The OBS Scale is a sensitive scale which is clinically useful for the description and long-term follow-up of patients showing symptoms of acute confusional state and dementia. Although the OBS scale has been used in several clinical studies there is need for further evaluation.

Keywords: OBS Scale; confusion; delirium; dementia; validity; reliability; MMSE; clinical usefulness. 


\title{
The Organic Brain Syndrome (OBS) Scale: A Systematic
}

\author{
Review
}

\section{Introduction}

Precise and reliable assessment of the mental status in elderly patients is essential as changes in cognition and behaviour often are the first symptom of an underlying psycho-physiologic disturbance (Foreman, 1987). A large number of rating scales have been designed for clinical assessment and diagnosis of organic mental disease. Many of these scales have been widely accepted and used without being subjected to a systematic analysis. Assessment instruments should meet the basic condition for acceptable psychometric characteristics such as presented by The Scientific Advisory Committee of the Medical Outcomes Trust (SAC), 2002. The SAC was created as a non-profit, international and independently operating entity with a commission to identify and review health status, functioning and quality of life instruments (Lohr et al., 1996). SAC defined eight attributes and review criteria, based on current norms and principles of modern test theory (McDowell and Newell, 1996; Streiner and Norman, 1995), as guidelines for the evaluation of such instruments. These guidelines, revised in 2002, have been applied in several evaluations of functioning and disability measurement scales (Kulich et al., 2003; Dziedzic et al., 2004; Höfer et al., 2004).

Within the field of emergency treatment and care there are increasing demands for specific and sensitive assessment tools for the evaluation of patients with an acute confusional state (ACS), delirium. ACS is probably the most frequent organic brain 
syndrome (OBS), especially among elderly with physical illness (Burns et al., 2004). Its physical and mental components are recognized as serious, painful, sometimes lifethreatening problems in the treatment and care of frail elderly patients (Inouye, 1998). Elderly patients with hip fracture constitute a group at high risk for developing ACS postoperatively (Gustafson, Y. et al., 1988). Studies concerning this group of patients have reported an incidence of ACS between 5\%-61.3\%, depending on the diagnostic tools and criteria used to detect this (Williams et al., 1985; Gustafson, Y. et al., 1988; Brauer et al., 2000; Andersson et al., 2001; Milisen et al., 2001; Burns et al., 2004).

The diagnosis of ACS as classified in The Diagnostic and Statistical Manual of Mental Disorders, fourth edition (DSM-IV) (1994), is based on four clinically key features: (1) disturbance of consciousness, (2) a change in cognition, (3) mental changes developing and often fluctuating over a short period of time, and (4) evidence that these disturbances are direct consequences of the general medical condition (American Psychiatric Association (APA), 1994).

The Organic Brain Syndrome scale (OBS scale) (Gustafson L et al., 1985; 1995) was developed for clinical evaluation of disturbances of awareness and orientation together with other signs of confusion in elderly patients. The development of the OBS scale was partially based on studies focusing upon dementia and the relationship between psychiatric symptoms and brain function as measured by regional blood flow (rCBF) (Gustafson L. et al., 1970; 1972; Gustafson L and Risberg, 1974) and psychometric testing (Gustafson L and Hagberg, 1975). The OBS scale was introduced as a 'new rating scale for evaluation of confusional states and organic brain syndromes' at the $2^{\text {nd }}$ International Congress of Psychogeriatric Medicine in 1985 (Gustafson, L et al., 
1985). The English version of the OBS scale was published in 1993 (Jensen et al., 1993). Bitsch et al. (2004) referred to the OBS scale as a standardized mental test similar to the Confusion assessment method (CAM) (Inouye, 1990). It is of considerable value to investigate to what extent the OBS scale fulfils the qualifications for clinical measurements.

\section{Aims}

The aims of this study were: (1) to critically examine the OBS Scale using the criteria and guidelines formulated by the SAC for the evaluation of assessment instruments; and (2) to investigate its relevance and suitability for use in various clinical settings.

\section{Method}

A two-stage strategy was used for identifying and reviewing papers for analyzation of the OBS scale. The first stage involved systematic search with quality library support, using data bases such as PubMed and Cinahl from 1966 to January 2005. MESH terms and keywords (confusion, delirium, acute confusional state, hip fractures, aged 65+, elderly, organic brain syndrome, and OBS Scale) were used in a variety of combinations resulting in 453 papers of which 431 were excluded as the OBS scale was not used. This was supplemented by manual searches from literature citations and reference lists resulting in eight papers. Only studies referring to the OBS scale, and 
original papers in English-language publications were included, which resulted in 30 papers selected for further consideration. The second stage included analyses of each one of the 30 papers selected in relation to the SAC's eight criteria for instrument assessments (SAC, 2002), and to clinical suitability.

\section{The SAC criteria for analysis}

The correlation of the data has been performed using SAC's principles and criteria for instrument assessments (SAC, 2002), which specifies the following eight attributes:

(1) Conceptual and measurement model. The conceptual model is the underlying rationale for and description of the concepts and the populations that the measure is intending to assess and the relationship between those concepts. The measurement model represents the instrument's scale and subscale structure and the procedures used for deriving scale scores.

(2) Reliability. Reliability is the degree to which an instrument is free from random error, i.e. its accuracy and reliability regardless of circumstances or location. The concept of reliability includes: (a) internal consistency, which reflects the precision of the scale based on the inter-correlation between the variables covered by the scale at any one time; and (b) reproducibility, i.e. the stability and reliability of the instrument used over a longer period of time (test - retest reliability, intra-rater and inter-rater reliability) during several administrations.

(3) Validity. Validity is the degree to which the instrument measures what it is intended to measure. This covers: (a) that it is content-related: that the domain of an instrument is appropriate to its intended use; (b) construct-related: evidence that endorse a proposed interpretation of scores based on theoretical implications associated with the constructs 
being measured; and (c) criteria-related: evidence which shows how the scores of the instrument are related and reflected to the stated criteria.

(4) Responsiveness refers to the instrument's ability to discern change over time.

(5) Interpretability is the degree to which the data and meaning of an instrument's quantitative scores can be easily understood.

(6) Respondent and administrative burden is the time, effort and other demands put on the respondents or on those who administer the instrument.

(7) Alternative forms of administration include other ways in which the instrument might be administered e.g. self-report, interviewer-administered or trained observer ratings.

(8) Cultural and language adaptations (translations) include assessment of conceptual and linguistic equivalence and evaluation of measurement characters (SAC, 2002).

\section{Results and Discussion}

\section{Evaluation in relation to the SAC's criteria}

The result of the analysis showed that in 18 (Table 1) of the 30 (Table 2) papers the criteria stated by the SAC were considered.

Insert Table 1

Insert Table 2

The conceptual and measurement model

The OBS scale consists of two subscales: 'OBS 1 - The disorientation subscale' and 'OBS 2 - The confusion subscale'. OBS 1 is an interview scale giving a short time 
perspective of the patient's condition with 16 questions (initially 15, where the first question : 'what is your name?' was separated into two questions, one for the first name, and one for the second name). OBS 1 describes the patients' awareness of and orientation to own identity (five items), time (seven items), place (two items), and knowledge regarding some general topics (two items). The patient is assessed according to a four - point ordinal scale with a detailed description given for each level (0-3) where zero indicates a correct response, while 1, 2 and 3 indicate slightly, moderately or completely wrong answers (Jensen et al., 1993; Gustafson L et al., 1995).

OBS 2, the second subscale, is an observation scale with 39 clinical items and with a longer time perspective. OBS 2 covers a broad spectrum of psychopathology: emotional reactions (nine items), different types of time related variations and fluctuations in the clinical condition (six items), suspiciousness and delusions (four items), language and speech difficulties (four items), neurological symptoms (three items), spatial disorientation and impaired recognition (6 items), physical and practical disabilities (five items), and social interaction skills (two items). The severity of the symptoms is ranked in four ordinal scale steps according to their intensity and frequency: Score zero indicates lack of any symptoms, 1, 2 and 3 scores represent occasional, moderate or obviously constant or recurring symptoms. The evaluation covers the latest seven day period, if not otherwise stated (Jensen et al., 1993; Gustafson L et al., 1995).

Factor analysis is a construct validity tool aiming at extracting and identifying underlying clinical dimensions (McDowell and Newell, 1996). Validity has been 
defined as the common variance of a factor, and construct validity is the meaning of this construct, studied by comparison with other constructions. Factor analysis, using the principal component method with orthogonal rotation, was used to determine the validity of the construction of the OBS scale, and to simplify the clinical description (Gustafson, L et al., 1985; Jensen et al., 1993; Gustafson L et al., 1995). The separation between OBS 1 and 2 and further development were based upon data obtained from 55 patients suffering from different levels of confusion or dementia (Table 1 and 2). A sub-sample of 20 patients with acute or sub-acute confusional reactions was followed during a double-blind drug trial. The factor analysis of the OBS 1 revealed three factors called Time, Recent memory and Identity and described by items with factor loadings between 0.40 and 0.87 (Table 3). All items had a high factor loading in at least one factor, and all except three items were unique for one factor (Jensen et al., 1993; Gustafson L et al., 1995).

Insert Table 3.

Factor analysis of the confusion scale (OBS 2) resulted in several separate factors describing different cognitive and emotional disturbances, and neurological features (Table 4). The 39 items were reduced to 38, as one item (“epileptic seizures") was excluded because of low symptom frequency (Gustafson, L et al., 1995). Nine factors emerged, described with factor loadings between 0.40 and 0.83 . Thirty-two items had one high factor loading, five had two, and one had three (Gustafson L et al., 1995).

Insert Table 4 
Both subscales exist in modified versions, OBS 1 reduced to 12 items, and the OBS 2 to 21 items in accordance with target population (Berggren et al., 1987). These modified OBS scales have been used in several studies (Table 2). Another modification was made by Hallberg et al. (1990) with the purpose of identifying common patterns of reduced functionality or derangements in a group of vocally disruptive patients compared with a control group. To ensure that the OBS 2 was sufficiently discriminative to identify the different levels of dementia, the confusion scale was modified from a four to a seven-point response scale (ibid.). This version was also used by Edberg et al. (1999) (Table 1 and 2).

\section{Reliability}

Seven studies showed high identical scoring of OBS 1 and OBS 2 regarding inter-rater reliability (Table 5). In the study by Gustafson, L et al. (1995), 55 patients were repeatedly assessed by a qualified geriatrician and 30 of these patients also assessed by a trained clinical psychologist. The inter-rater reliability was significant $\left(r_{s}=0.71-\right.$ $\left.1.0, r_{s}=0.61-1.0\right)$. A discrepancy between the raters concerning only one of the symptoms in the OBS 2 disappeared after a minor modification of the item description (Gustafson L et al., 1995). Hallberg et al. (1990) showed an inter-rater reliability of $r_{s}=0.93-0.98$, the assessments performed by experienced nurses. Ninety-eight percent of the assessments in the studies by Gustafson, Y et al. (1988; 1991a) were performed by the same geriatrician, and the remaining by a co-author. In the same research group Berggren et al. (1987) reported a 90\% agreement for all variables between two investigators whereas Brännström et al. (1989) showed a 95\% agreement on all occasions between two raters. Later studies by the same group have shown more than $90 \%$ consensus between raters (Edlund et al., 2001). The internal consistency, 
reported by Edberg et al. (1999), as measured by Cronbach's alpha, showed an overall reliability of 0.88 for the OBS 2, which is considered as sufficient (Nunnally and Bernstein, 1994).

Thus the OBS scale has shown satisfactory inter-rater reliability, in several studies carried out by experienced researchers and clinicians with a recognized and acknowledged competence within the specific field. Other forms of reliability such as test-retest and intra-class correlations have not been used.

Insert Table 5

\section{Validity}

The construct-related validity of the confusion subscale (OBS 2) was tested by comparing OBS 2 and its clinical dimensions described by the nine factors, with the results of previous factor analyses carried out on five other commonly used psychogeriatric scales (Gustafson, L et al., 1995): The Stockton Geriatric Rating Scale (SGRS) (Meer and Baker, 1966), Psychiatric symptomatology in senile dementia (Jonsson et al., 1972), Psychiatric symptoms in presenile dementia (Gustafson, L, 1975), The Sandoz Clinical Assessment-Geriatric (SCAG) rating scale (Shader et al., 1974) and The Brief Psychiatric Rating Scale (BPRS) (Overall and Beller, 1984). The factors in the confusion scale (OBS 2) showed strong similarity to the factor solutions of the five psychogeriatric rating scales (Gustafson, L et al., 1995).

Hallberg et al. (1990) in a discriminant analysis compared patients with and without vocally disruptive behaviour in a larger cohort $(n=264)$ of psychogeriatric patients 
(Table 3). There were only small differences between the two patient groups in OBS 1, while in OBS 2 five of the seven factors were of significant importance for group classification. The vocally disruptive behaviour was significantly related to the patients' functional capacity, orientation in the ward, clinical fluctuations and emotional instability, as well as hallucinations and delusions. Speech dysfunction and a more placid temperament were more marked in the control group. Thus the OBS 1 showed important similarities, while the OBS 2 revealed several clinically relevant differences between the patient groups, indicating a predictive usefulness of the OBS scale.

The construct and the clinical dimensions of the OBS scale have been described in similar ways by two independent factor analyses. The three factors of the OBS 1 are described by several items with strong factor loadings, fulfilling the requirements of Gorsuch (1983), that the factors should on average contain about five strong variables and that the number of observations should be at least five times as many as there are variables to be analyzed. This would ensure that the total number of observations would be sufficient to regard the factor analysis of the OBS 1 as reliable. The number of observations in the OBS 2 in the study by Gustafson, L et al. (1995) was, however, slightly below these recommendations to ensure factor analytic reliability (Gorsuch, 1983). The structures of the factors as revealed in the rotated factor matrix were judged as significant on the $1 \%$ level and were considered as practically identical (Jensen et al., 1993) which give an evidence of construct-related validity. 
The OBS Scale has shown a satisfactory content-related validity since every item except for one (epileptic seizures) relates to the different clinical dimensions describing organic mental disease (Hallberg et al., 1990; Gustafson L et al., 1995).

Criterion-related validity, usually divided into concurrent and predictive validity (McDowell and Newell, 1996), of the OBS Scale was further evaluated by comparing it with the Mini-Mental-State-Examination (MMSE) (Folstein et al., 1975) and the Gottfries, Bråne and Steen (GBS) Scale (Gottfries et al., 1982) (Jensen et al., 1993). Both scales have been translated into several languages and are widely used in clinical practice and research. Twenty-eight patients with different forms of dementia were assessed with the OBS Scale, the MMSE, and the GBS Scale together with the Global Deterioration Scale (GDS) (Reisberg et al., 1982), and the Katz ADL index (Katz and Akpom, 1976) (Table 1, 2). The GBS Scale describes different clinical dimensions such as intellectual, emotional and motor functions, and other symptoms usually shown in patients with dementia. The GDS is based upon a clinical evaluation of the patient's total functional abilities. The comparisons between the OBS Scale, the MMSE, and the GBS Scale were based upon correlations between the patient's scores in the assessment scales, the subscales and the factors (Jensen et al., 1993). Concurrent validity was satisfactory as the correlations between the score in the whole of the total OBS Scale, and the MMSE and GBS Scales were high. The MMSE score correlated significantly $(\mathrm{p}<0.01-\mathrm{p}<0.001)$ with the scores in the OBS Scale $\left(r_{s}=-0.83\right)$, the OBS $1\left(r_{s}=-0.56\right)$, the OBS $2\left(r_{s}=-0.75\right)$, and the GBS scale $\left(r_{s}=-0.80\right)$. The OBS Scale also showed significant correlations with all other assessment scales (GBS Scale: $r_{s}=0.82$, GDS: $\left.r_{s}=0.57\right)$, with the lowest correlation $(\mathrm{p}<0.05)$ with the Katz ADL index $\left(r_{s}=0.43\right)$. The OBS 2 showed similar results, although with somewhat stronger 
correlations with the GDS and the Katz ADL index, here used as a measure of discriminant validity. This was further supported by Minthon et al. (1996) presenting strong correlations between MMSE score and scores in the factor "dyspraxia - spatial disorientation" in the OBS 2 scale $(r=0.78, \mathrm{p}<.0001$, Mann-Whitney $U$ test $)$. OBS 1 showed a significant $(\mathrm{p}<0.01)$ correlation with the GBS scale $\left(r_{s}=0.56\right)$, but not with the GDS and the Katz ADL index (Jensen et al., 1993). The mainly low and nonsignificant correlations between patients' scores in the 12 factors in OBS 1 and OBS 2 emphasized the strength and stability of the factor structure. The comparisons with other clinical rating scales clearly showed their ability to describe, identify and assess a wide range of clinical dimensions (Jensen et al., 1993). This study is one of the very few where the analysis of the MMSE scale has been based on patients with a wide range of organic and functional diagnoses. This limitation of earlier studies has been pointed out as one of the shortcomings regarding the utility of the MMSE in the detection of dementia (Field et al., 1995).

A study focusing upon a single item 'depressed mood' in the OBS 2 scale showed strong correlations with the Montgomery-Åsberg Depression Rating Scale (MADRS) (Montgomery and Åsberg, 1979) and The Clinical Global Impression (CGI) Scale (Guy, 1976) (MADRS: $r_{s}$ 0.85, CGI scale: $r_{s}$ 0.88) (Sandberg et al., 1998). Assessment of 457 patients regarding confusion and level of disorientation was made by Andersson et al. (2001). The agreement between the clinical assessments based on the criteria stated in DSM-IV, and the scores on the OBS 1 showed a Kappa-coefficient of 0.77 (95\% confidence interval $0.71-0.83$ ) and the exact agreement was $96.2 \%$ (Andersson et al., 2001). The OBS scale was compared with the CAM (Inouye, 1990) showing a $100 \%$ agreement regarding the diagnosis of postoperative ACS as classified in the 
DSM-IV (Eriksson et al., 2002). The distinction between ACS and non- ACS was highly significant $(\mathrm{p}=0.021-\mathrm{p}<0.001$, Fischer's exact test $)$ in four clinical items. Another strong correlation between the OBS 1 scores and the scores in the MMSE (Pearson $r=-0.899, \mathrm{p} \leq 0.001$ ) was presented by Lundström et al. (2003) giving evidence of a satisfactory criterion-related validity (Table 1 and 2).

\section{Responsiveness}

Patients showing symptoms of ACS were tested repeatedly on a daily basis until, and if, their confusion had ceased (Andersson et al., 2001). Even as early as at the admission to the hospital there were significantly higher OBS 1 scores in patients who later developed ACS. The authors maintain that the OBS 1 was sufficiently sensitive to recognize, at an early stage, those patients who are at risk to develop an ACS. In several studies the OBS 1 and 2 were used to detect and follow the clinical course of ACS (Berggren et al., 1987; Edlund et al., 2001; Gustafson Y et al., 1988; 1991a; Lundström et al., 1999; 2003). All patients in the study by Gustafson L et al. (1985; 1995) could be described by standardized factor scores in the different symptom clusters, based on factor analysis, and the symptom profile could be followed during treatment of the confusional state.

\section{Interpretability}

The clinical assessment with the OBS 1 was based on a four point scale (total range $0-48)$ with a detailed and well-defined description of each step for every item. For example, the eighth item, 'What day of the week is it?' the following scores/steps were given: (0) correct answer, (1) wrong by one day, (2) knows whether it is the beginning, 
in the middle or at the end of the week, and (3) answer completely wrong or no reply. The questions in the OBS 2 scale were formulated to reflect the severity and variation of the symptoms, ranked in four levels based on intensity and frequency of each symptom and item (total range $1-117)$. For example, the item "Restlessness" had following scores/steps: (0) not observed, (1) difficulty in keeping hands still, changes posture, (2) marked restlessness, hand wringing and attempt to rise, and (3) inability to sit still for more than short periods, pacing (Jensen et al., 1993; Gustafson L et al., 1995). As a cut-off score Berggren et al. (1987) suggested six points or less within three items in the modified OBS 1. Higher score indicated increased disorientation. The same cut-off score was used by Andersson et al. (2001) while Nyberg et al. (1996) considered the patient as lucid at nine points or less, out of a maximum of 36 points. The majority of studies also used the DSM-criteria for delirium in defining the patient as confused, which should confirm the grading of scores (Table 1 and 2).

\section{Respondent and administrative burden}

The assessment using the OBS 1 takes approximately $5-10 \mathrm{~min}$ and is possible to integrate into ordinary nursing assessment (Andersson et al., 2001). About 30 min was enough to complete the OBS Scale, for an experienced interviewer and a cooperative patient (Jensen et al., 1993). The interview itself took approximately $10-15 \mathrm{~min}$, and the patients never complained of feeling tired during the actual investigation. The assessment with both subscales took about 1h (Sandberg et al., 1999). Further information concerning burden hasn't been found which could indicate that the scale isn't too strenuous to administer, nor for the respondent to answer or respond to. 


\section{Alternative forms of administration}

The OBS 1 scale is based on a limited number of questions on awareness and orientation to which the patient is expected to respond. Patients' mental status before the fracture may be judged by interviews with relatives and care staff (Gustafson, Y. et al., 1991c; Edlund et al., 2001) and the observational schedule of the confusion scale, OBS 2, may be grounded on information given by nurses and other staff members, well acquainted with the patient's condition and behavioural patterns, and with special training of patients with organic mental disease (Jensen et al., 1993; (Gustafson, L. et al., 1995). Other forms of administration have not been used.

\section{Cultural and language adaptations (translations)}

The selection and formulation of the items in the OBS Scale were based on a comprehensive review of literature concerning psychogeriatric assessment scales, using Scandinavian research traditions and approaches. The questions in the orientation subscale also fulfill those commonly used to establish the clinical assessment of patients suffering of organic brain failure (Jensen et al., 1993). The OBS Scale has been published in its original Swedish form and has been recommended for assessment of acute confusion in the Norwegian geriatric-psychiatric treatment and care (INFO-banken, 1996). Although the OBS Scale was originally founded on Swedish clinical concepts and tradition, it has shown a satisfactory concordance with other rating scales in the field of organic mental disease. 


\section{Evaluation in relation to clinical relevance and suitability}

The structure of the OBS Scale and its clinical applicability has been studied in different clinical settings and patient populations with a wide range of age from 23 years to 102 years (Table 2). The majority of studies took place at different departments and hospitals in Sweden. In several studies the OBS Scale has been used to investigate the incidence of ACS and to follow the development of this condition, dementia, different psychiatric profiles and behavioural as well as cognitive symptoms in the elderly population. It has been applied on orthopedic patients, stroke patients, patients in coronary heart and intensive care units (ICU), showing good responsiveness and comprehensibility in a number of clinical conditions.

Assessing mental status in geriatric patients the OBS 1 Scale may well be used as it doesn't include writing and drawing, difficult tasks to standardize for elderly bedridden or otherwise disabled patients. Compared to other mental tests, in which the patient is assessed according to a nominal scale (right/wrong answer), the OBS Scale offers several well defined scoring steps which should make it more sensitive to changes in the patient's mental condition. Moreover, the assessment procedure with the OBS Scale is always started with three relevant questions concerning the patients' hearing, vision and speech.

The conformity of the scale with the criteria stated in DSM-III, DSM-III-R and DSMIV (APA, 1980; 1987; 1994) have been supported by several studies (Berggren et al., 1987; Sandberg et al., 1998; Andersson et al., 2001). The tests and crossevaluations carried out in these studies strongly confirm the reliability of the diagnosis 
of acute confusion and thus a confirmation of the usefulness in the populations for which the OBS Scale was intended; a conclusion further supported by the literature which has been examined and studied.

\section{Conclusions}

The OBS scale is a sensitive and balanced rating scale offering description of a wide spectrum of clinical manifestations in organic brain disease. It is easy to apply on different patient samples in different clinical settings. The rating scale shows strong conformity with other rating scales used in this clinical context. The OBS Scale in many aspects satisfies the requirements of a valid clinical instrument, though with respect to the criteria suggested by the SAC (2002) there is a need for additional evaluation of the OBS Scale, especially with regard to reliability, and the translation and adaptation to other languages.

Acknowledgements: The study was supported by grants from The Swedish Research Council (Project no 3950). 


\section{References}

American Psychiatric Association (APA). 1980. DSM-III: Diagnostic and Statistical Manual of Mental Disorders ( $3^{\text {rd }}$ ed.). American Psychiatric Association (APA): Washington, DC.

American Psychiatric Association (APA). 1987. DSM III-R: Diagnostic and Statistical Manual of Mental Disorders ( $3^{\text {rd }}$ revised ed.). American Psychiatric Association (APA): Washington, DC.

American Psychiatric Association (APA). 1994. DSM IV: Diagnostic and Statistical Manual of Mental Disorders ( $4^{\text {th }}$ ed.). American Psychiatric Association (APA): Washington, DC.

Andersson EM, Gustafson L, Hallberg IR. 2001. Acute confusional state in elderly orthopaedic patients: factors of importance for detection in nursing care. Int J Geriatr Psychiatry 16(1):7-17.

Andersson EM, Knutsson IK, Hallberg IR, Norberg A. 1993. The experience of being confused: a case study. A breakdown in communication between a confused patient and a nurse may have everything to do with the nurse's point of view. Geriatr Nurs 14(5):242-7.

Berggren D, Gustafson Y, Eriksson B, Bucht G, Hansson LI, Reiz S, Winblad B. 1987. Postoperative confusion after anesthesia in elderly patients with femoral neck fractures. Anesth Analg 66(6):497-504.

Bitsch M, Foss N, Kristensen B, Kehlet H. 2004. Pathogenesis of and management strategies for postoperative delirium after hip fracture: a review. Acta Orthop Scand 75(4):378-89.

Brauer C, Morrison RS, Silberzweig SB, Siu AL. 2000. The cause of delirium in patients with hip fracture. Arch Intern Med 160(12):1856-1860. 
Brännström B, Gustafson Y, Norberg A, Winblad B. 1989. Problems of basic nursing care in acutely confused and non-confused hip-fracture patients. Scand J Caring Sci $3(1): 27-34$.

Brännström B, Gustafson Y, Norberg A, Winblad B. 1991. ADL performance and dependency on nursing care in patients with hip fractures and acute confusion in a task allocation care system. Scand J Caring Sci 5(1):3-11.

Burns A, Gallagley A, Byrne J. 2004. Delirium. J Neurol Neurosurg Psychiatry 75(3):362-7.

Dziedzik KS, Thomas E, Hay EM. 2004. A systematic search and critical review of measures of disability for use in a population survey of hand osteoarthritis (OA). Osteoarthritis Cartilage 13:1-12.

Edberg AK, Norberg A, Hallberg IR. 1999. Mood and general behavior of patients with severe dementia during one year of supervised, individualized planned care and systematic clinical supervision. Comparison with a similar control group. Aging (Milano) 11(6):395-403.

Edlund A, Lundström M, Brännström B, Bucht G, Gustafson Y. 2001. Delirium before and after operation for femoral neck fracture. J Am Geriatr Soc 49(10):1335-40.

Edlund A, Lundström M, Brännström B, Bucht G, Gustafson Y. 1999. Clinical Profile of Delirium in Patients Treated for Femoral Neck Fractures. Dement Geriatr Cogn Disord 10:325-329.

Elmståhl S, Annerstedt L, Åhlund O. 1997. How should a group living unit for demented elderly be designed to decrease psychiatric symptoms? Alzheimer Dis Assoc Disord 11(1):47-52.

Eriksson M, Samuelsson E, Gustafson Y, Åberg T, Engström KG. 2002. Delirium after coronary bypass surgery evaluated by the organic brain syndrome protocol. Scand Cardiovasc J 36(4):250-5. 
Field SJ, Jackson HJ, Hassett AM, Pattison P. 1995. Ability of the mini-mental state examination to discriminate diagnostic entities in a psychogeriatric population. Int J Geriatr Psychiatry 10: 47-53.

Folstein MF, Folstein SE, McHugh PR. 1975. "Mini-mental state". A practical method for grading the cognitive state of patients for the clinician. J Psychiatr Res 12(3):189-98.

Foreman MD. 1987. Reliability and validity of mental status questionnaires in elderly hospitalized patients. Nurs Res 36(4):216-20.

Gorsuch RL. 1983. Factor analysis. Lawrence Erlbaum Associates Publishers: New Jersey and London.

Gottfries CG, Bråne G, Gullberg B, Steen G. 1982. A new rating scale for dementia syndromes. Arch Gerontol Geriatr 1(4):311-30.

Granberg-Axell A, Bergbom I, Lundberg D. 2001. Clinical signs of ICU syndrome/delirium: an observational study. Intensive Crit Care Nurs 17(2):72-93.

Gustafson L. 1975. Psychiatric symptoms in dementia with onset in the presenile period. Acta Psychiatr Scand 257(Suppl.):8-35.

Gustafson L, Hagberg B. 1975. Dementia with onset in the presenile period. A crosssectional study. Acta Psychiatr Scand 257 (Suppl):39-67.

Gustafson L, Hagberg B, Holley JW, Risberg J, Ingvar DH. 1970. Regional cerebral blood flow in organic dementia with early onset. Correlations with psychiatric symptoms and psychometric variables. Acta Neurol Scand 43 (Suppl):74-5.

Gustafson L, Lindgren M, Westling B. 1985. The OBS Scale. A new rating scale for evaluation of confusional states and other organic brain syndromes. In $2^{\text {nd }}$ International Congress on Psychogeriatric Medicine Abstract No. 128, Umeå, Sweden. 
Gustafson L, Lindgren M, Westling B. 1995. The OBS Scale. A factor analysis approach to evaluation of confusional states and other Organic Brain Syndromes. Departments of Psychogeriatrics, Lund University. http://www.psykiatr.lu.se/pg/OBSscale.pdf

Gustafson L, Risberg J. 1974. Regional cerebral blood flow related to psychiatric symptoms in dementia with onset in the presenile period. Acta Psychiatr Scand 50(5):516-38.

Gustafson L, Risberg J, Hagberg B, Nilsson L, Ingvar DH. 1972. Cerebral blood flow and psychometric variables related to psychiatric findings in presenile dementia. In: Gerontopsychiatrie 2, Kanowski S (ed.). Janssen Symposien, Janssen: Dusseldorf; 84-103.

Gustafson Y, Berggren D, Brännström B, Bucht G, Norberg A, Hansson LI, Winblad B. 1988. Acute confusional states in elderly patients treated for femoral neck fracture. $J$ Am Geriatr Soc 36(6):525-30.

Gustafson Y, Brännström B, Norberg A, Bucht G, Winblad B. 1991b. Underdiagnosis and poor documentation of acute confusional states in elderly hip fracture patients. $J \mathrm{Am}$ Geriatr Soc 39(8):760-5.

Gustafson Y, Brännström B, Berggren D, Ragnarsson JI, Sigaard J, Bucht G, Reiz S, Norberg A, Winblad B. 1991a. A geriatric-anesthesiologic program to reduce acute confusional states in elderly patients treated for femoral neck fractures. J Am Geriatr Soc 39(7):655-62.

Gustafson Y, Olsson T, Asplund K, Hägg E. 1993. Acute Confusional State (Delirium) Soon after Stroke is Associated with Hypercortisolism. Cerebrovasc Dis 3:33-38.

Gustafson Y, Olsson T, Eriksson S, Asplund K, Bucht G. 1991c. Acute confusional states (delirium) in stroke patients. Cerebrovasc Dis 1:257-265.

Guy W. 1976. Clinical Global Impressions. Early clinical drug evaluation unit (ECDEUNational Institute of Health);218-22. 
Hallberg IR, Norberg A, Erikson S. 1990. Functional impairment and behavioural disturbances in vocally disruptive patients in psychogeriatric wards compared with controls. Int J Geriatr Psychiatry 5:53-61.

Höfer S, Lim L, Guyatt G, Oldridge N. 2004. The MacNew Heart Disease health-related quality of life instrument: A summary. Health Qual Life Outcomes 2(1):3.

Holmquist IB, Svensson B, Höglund P. 2003. Psychotropic drugs in nursing- and old-age homes: relationships between needs of care and mental health status. Eur J Clin Pharmacol 59(8-9):669-76.

INFO-banken. 1996. Håndbok for skalaer i klinisk alderspsykiatri. Norsk Alderspsykiatri (Norweigan national program for development for old age psychiatry), Vestfold Sentralsykehus, Psykiatrisk klinnik.

Inouye SK. 1998. Delirium in hospitalized older patients. Clin Geriatr Med 14(4):745-64.

Inouye SK, van Dyck CH, Alessi CA, Balkin S, Siegal AP, Horwitz RI. 1990. Clarifying confusion: the confusion assessment method. A new method for detection of delirium. Ann Intern Med 113(12):941-8.

Jensen E, Dehlin O, Gustafson L. 1993. A comparison between three psychogeriatric rating scales. Int J Geriatr Psychiatry 8:215-229.

Jonsson CO, Waldton S, Mälhammar G. 1972. The psychiatric symptomatology in senile dementia assessed by means of an interview. Acta Psychiatr Scand 48(2):103-21.

Katz S, Akpom CA. 1976. A measure of primary sociobiological functions. Int $J$ Health Serv 6(3):493-508.

Kulich KR, Malfertheiner P, Madisch A, Labenz J, Bayerdorffer E, Miehlke S, Carlsson J, Wiklund IK. 2003. Psychometric validation of the German translation of the Gastrointestinal Symptom Rating Scale (GSRS) and Quality of Life in Reflux and Dyspepsia (QOLRAD) questionnaire in patients with reflux disease. Health Qual Life Outcomes 1(1):62. 
Lohr KN, Aaronson NK, Alonso J, Burnam MA, Patrick DL, Perrin EB, Roberts JS. 1996. Evaluating quality-of-life and health status instruments: development of scientific review criteria. Clin Ther 18(5):979-92.

Lundström M, Edlund A, Bucht G, Karlsson S, Gustafson Y. 2003. Dementia after delirium in patients with femoral neck fractures. J Am Geriatr Soc 51(7):1002-6.

Lundström M, Edlund A, Karlsson S, Brännström B, Bucht G, Gustafson Y. 2005. A multifactorial intervention program reduces the duration of delirium, length of hospitalization, and mortality in delirious patients. J Am Geriatr Soc 53 (4): 622-628.

Lundström M, Edlund A, Lundström G, Gustafson Y. 1999. Reorganization of nursing and medical care to reduce the incidence of postoperative delirium and improve rehabilitation outcome in elderly patients treated for femoral neck fractures. Scand $J$ Caring Sci 13(3):193-200.

McDowell I, Newell, C. 1996. Measuring Health: a guide to rating scales and questionnaires. Oxford University Press: New York.

Meer B, Baker JA. 1966. The Stockton Geriatric Rating Scale. J Gerontol 21(3):392-403.

Milisen K, Foreman MD, Abraham IL, De Geest S, Godderis J, Vandermeulen E, Fischler B, Delooz HH, Spiessens B, Broos PL. 2001. A nurse-led interdisciplinary intervention program for delirium in elderly hip-fracture patients. J Am Geriatr Soc 49(5):523-32.

Minthon L, Edvinsson L, Gustafson L. 1996. Correlation between clinical characteristics and cerebrospinal fluid neuropeptide Y levels in dementia of the Alzheimer type and frontotemporal dementia. Alzheimer Dis Assoc Disord 10(4):197-203.

Montgomery SA, Åsberg M. 1979. A new depression scale designed to be sensitive to change. Br J Psychiatry 134:382-9.

Nilsson K, Warkentin S, Hultberg B, Fäldt R, Gustafson L. 2000. Treatment of cobalamin deficiency in dementia, evaluated clinically and with cerebral blood flow measurements. Aging (Milano) 12(3):199-207. 
Nunnally JC, Bernstein IH. 1994. Psychometric theory. McGraw-Hill: New York.

Nyberg L, Gustafson Y, Berggren D, Brännström B, Bucht G. 1996. Falls leading to femoral neck fractures in lucid older people. J Am Geriatr Soc 44:156-160.

Overall JE, Beller SA. 1984. The Brief Psychiatric Rating Scale (BPRS) in geropsychiatric research: I. Factor structure on an inpatient unit. J Gerontol 39(2):18793.

Reisberg B, Ferris SH, de Leon MJ, Crook T. 1982. The Global Deterioration Scale for assessment of primary degenerative dementia. Am J Psychiatry 139(9):1136-9.

Sandberg O, Franklin KA, Bucht G, Gustafson Y. 2001. Sleep apnea, delirium, depressed mood, cognition, and ADL ability after stroke. J Am Geriatr Soc 49(4):391-7.

Sandberg O, Gustafson Y, Brännström B, Bucht G. 1998. Prevalence of dementia, delirium and psychiatric symptoms in various care settings for the elderly. Scand J Soc Med 26(1):56-62.

Sandberg O, Gustafson Y, Brännström B, Bucht G. 1999. Clinical profile of delirium in older patients. J Am Geriatr Soc 47(11):1300-6.

Scientific Advisory Committee of the Medical Outcomes Trust (SAC). 2002. Assessing health status and quality-of-life instruments: attributes and review criteria. Qual Life Res 11(3):193-205.

Shader RI, Harmatz JS, Salzman C. 1974. A new scale for clinical assessment in geriatric populations: Sandoz Clinical Assessment-Geriatric (SCAG). J Am Geriatr Soc 22(3):107-13.

Streiner DL, Norman GR. 1995. Health measurement scales: a practical guide to their development and use. Oxford University Press: Oxford.

Williams MA, Campbell EB, Raynor WJ, Jr., Musholt MA, Mlynarczyk SM, Crane LF. 1985. Predictors of acute confusional states in hospitalized elderly patients. Res Nurs Health 8(1):31-40. 


\section{Tables and Legends}

Table 1. Evaluation of the OBS scale (OBS 1+ OBS 2) in 18 studies according to the SAC's eight attributes and guidelines (SAC, 2001)

Table 2. Data in chronological order from 30 studies concerning confusion or psychiatric illness using OBS scale.

Table 3. Two different factor analyses of the disorientation subscale, OBS 1.

Table 4. Two different factor analyses of the confusion subscale, OBS 2.

Table 5. Inter-rater reliability tests of the OBS scale (OBS 1 and OBS 2) in elderly orthopedic and psychiatric patients. 
Table 1. Evaluation of the OBS Scale (OBS 1+ OBS 2) in 18 studies in relation to the SAC's eight attributes and guidelines (SAC, 2001)

\begin{tabular}{|c|c|c|c|c|c|c|c|c|}
\hline Source & \begin{tabular}{|l|}
$\begin{array}{l}\text { Conceptual } \\
\text { measurement } \\
\text { model }\end{array}$ \\
\end{tabular} & Reliability & Validity & Responsiveness & Interpretability & \begin{tabular}{|l|}
$\begin{array}{l}\text { Respondent, } \\
\text { administrative } \\
\text { burden }\end{array}$ \\
\end{tabular} & \begin{tabular}{|l}
$\begin{array}{l}\text { Alternative } \\
\text { forms }\end{array}$ \\
\end{tabular} & \begin{tabular}{|l|} 
Cultural, language \\
adaptations
\end{tabular} \\
\hline $\begin{array}{l}\text { Andersson } \\
\text { et al., } 2001\end{array}$ & & & \begin{tabular}{|l|} 
Exact agreement \\
OBS 1 / DSM-IV
\end{tabular} & \begin{tabular}{|l|} 
OBS 1 \\
Sensitivity to \\
changes, \\
prediction \\
\end{tabular} & $\begin{array}{l}\text { Cut-off: } 6 \text { points or less } \\
\text { out of } 36 \text { in a maximum } \\
\text { of } 3 \text { items. Diagnostic } \\
\text { criteria DSM-IV } \\
\end{array}$ & \begin{tabular}{|l|} 
OBS 1 \\
Integrated in \\
nurs.ass. $5-10$ \\
min. \\
\end{tabular} & \begin{tabular}{|l} 
Experienced \\
nurses/other \\
care staff spec. \\
trained \\
\end{tabular} & \\
\hline $\begin{array}{l}\text { Berggren et al., } \\
1987\end{array}$ & $\begin{array}{l}\text { Modified version } \\
\text { in number of } \\
\text { items }\end{array}$ & Inter-rater & & $\begin{array}{l}\text { OBS } 1+2 \\
\text { Sensit.to changes }\end{array}$ & $\begin{array}{l}\text { Cut-off: } 6 \text { points or less } \\
\text { out of } 36 \text { in a maximum } \\
\text { of } 3 \text { items. DSM-III }\end{array}$ & & & $\begin{array}{l}\text { OBS 1: English } \\
\text { version }\end{array}$ \\
\hline $\begin{array}{l}\text { Brännström et al., } \\
1989\end{array}$ & & Inter-rater & & \begin{tabular}{|l|} 
OBS $1+2$ \\
Sensit.to changes \\
\end{tabular} & Diagn.crit. DSM-III & & & \\
\hline Edberg et al., 1999 & & \begin{tabular}{|l} 
Intern consist.: \\
OBS 2
\end{tabular} & & \begin{tabular}{|l|} 
OBS $1+2$ \\
Sensit.to changes \\
\end{tabular} & & & & \\
\hline Edlund et al., 2001 & & Inter-rater & & $\begin{array}{l}\text { OBS } 1+2 \\
\text { Sensit.to changes } \\
\end{array}$ & Diagn. crit. DSM-IV & & \begin{tabular}{|l|} 
Interviews \\
relatives, staff
\end{tabular} & \\
\hline $\begin{array}{l}\text { Eriksson et al. } \\
2002\end{array}$ & & & \begin{tabular}{|l|} 
Exact agreement \\
OBS scale:4 variables \\
/ CAM / DSM-IV \\
\end{tabular} & & Diagn. crit. DSM-IV & & & \\
\hline $\begin{array}{l}\text { Gustafson L } \\
\text { et al. 1985; } \\
1995\end{array}$ & \begin{tabular}{|l|} 
Concepts \\
Dimensions \\
Scale level, \\
scores, target \\
population \\
\end{tabular} & Inter-rater & \begin{tabular}{|l|} 
Factor analysis \\
OBS 2 / 5 \\
psychogeriatric scales
\end{tabular} & $\begin{array}{l}\text { OBS } 1+2 \\
\text { Sensit.to changes } \\
\text { Evaluation of } \\
\text { treatment }\end{array}$ & \begin{tabular}{|l|} 
OBS 1, OBS 2 \\
Score structure presented.
\end{tabular} & & $\begin{array}{l}\text { Nurses/other } \\
\text { care staff spec. } \\
\text { trained }\end{array}$ & $\begin{array}{l}\text { Precise descriptions } \\
\text { and grading of } \\
\text { observations . }\end{array}$ \\
\hline $\begin{array}{l}\text { Gustafson Y et al. } \\
1988\end{array}$ & & Inter-rater & & \begin{tabular}{|l} 
OBS $1+2$ \\
Sensit. o changes \\
\end{tabular} & Diagn.crit. DSM-III & & & \\
\hline $\begin{array}{l}\text { Gustafson Y et al. } \\
\text { 1991a }\end{array}$ & & Inter-rater & & $\begin{array}{l}\text { OBS } 1+2 \\
\text { Sensit.to changes } \\
\end{array}$ & Diagn.crit. DSM-III & & & \\
\hline $\begin{array}{l}\text { Gustafson Y et al. } \\
\text { 1991c }\end{array}$ & & & & & & & \begin{tabular}{|l|l|}
$\begin{array}{l}\text { Interviews } \\
\text { relatives, staff }\end{array}$ \\
\end{tabular} & \\
\hline $\begin{array}{l}\text { Hallberg et al. } \\
1990\end{array}$ & $\begin{array}{l}\text { Modified in scale } \\
\text { steps }\end{array}$ & Inter-rater & \begin{tabular}{|l} 
Factor analysis \\
Discriminant validity
\end{tabular} & & & & & \\
\hline Jensen et al. 1993 & & & $\begin{array}{l}\text { Concurrent/ } \\
\text { discriminant validity } \\
\text { MMSE / GBS }\end{array}$ & & \begin{tabular}{|l} 
OBS 1, OBS 2 Score \\
structure and levels \\
presented. DSM-III-R
\end{tabular} & $\begin{array}{l}\text { OBS } 1+230 \mathrm{~min} . \\
\text { no complaints/ } \\
\text { tiredness }\end{array}$ & \begin{tabular}{|l} 
Nurses/other \\
care staff spec. \\
trained
\end{tabular} & $\begin{array}{l}\text { OBS 1+2: English } \\
\text { version Scandinavian } \\
\text { research tradition }\end{array}$ \\
\hline $\begin{array}{l}\text { Lundström et al. } \\
2003\end{array}$ & & & \begin{tabular}{|l} 
Concurrent validity \\
OBS 1 / MMSE \\
\end{tabular} & \begin{tabular}{|l} 
OBS $1+2$ \\
Sensit.to changes \\
\end{tabular} & Diagn. crit. DSM-IV & & & \\
\hline $\begin{array}{l}\text { Lundström et al. } \\
2005\end{array}$ & & & & \begin{tabular}{|l|} 
OBS $1+2$ \\
Sensit.to changes
\end{tabular} & Diagn. crit. DSM-IV & & & \\
\hline Minthon et al. 1996 & & & \begin{tabular}{|l|} 
Correlation OBS 2: \\
dyspraxia-spatial \\
disorient./ MMSE \\
\end{tabular} & & \begin{tabular}{|l|} 
Diagn.crit. \\
DSM-III-R
\end{tabular} & & & \\
\hline Nyberg et al. 1996 & & & & & $\begin{array}{l}\text { Cut-off: } 9 \text { points or less } \\
\text { out of } 36 \text { items }\end{array}$ & & & \\
\hline $\begin{array}{l}\text { Sandberg et al. } \\
1998\end{array}$ & & & $\begin{array}{l}\text { Concurrent validity: } \\
\text { OBS 2, depr.mood / } \\
\text { MADRS / CGI }\end{array}$ & & $\begin{array}{l}\text { Diagn. crit. } \\
\text { DSM-III-R }\end{array}$ & & & \\
\hline $\begin{array}{l}\text { Sandberg et al. } \\
1999\end{array}$ & & & & $\begin{array}{l}\text { OBS } 1+2 \\
\text { Sensit. to } \\
\text { changes }\end{array}$ & $\begin{array}{l}\text { Diagn. crit. } \\
\text { DSM-III-R }\end{array}$ & $\begin{array}{l}\text { OBS } 1+2 \\
\text { One hour }\end{array}$ & \begin{tabular}{l}
\multicolumn{1}{|c}{ Experienced } \\
nurses/other \\
care staff spec. \\
trained
\end{tabular} & \\
\hline
\end{tabular}

Article for submission for Int J Geriatr Psychiatry, 20-07-05 KBB 
Table 2. Data in chronological order from 30 studies concerning confusion or psychiatric illness using the OBS scale

\begin{tabular}{|c|c|c|c|c|c|c|c|}
\hline \multirow[t]{2}{*}{ Source } & \multirow[t]{2}{*}{$n$} & \multirow[t]{2}{*}{ Population } & \multirow[t]{2}{*}{ Age } & \multirow[t]{2}{*}{ Study aim } & \multicolumn{2}{|c|}{ Diagnostic instruments } & \multirow{2}{*}{$\begin{array}{l}\text { Diagnosis/ } \\
\text { Diagnostic criteria }\end{array}$} \\
\hline & & & & & $\begin{array}{l}\text { OBS } \\
\text { scale }\end{array}$ & $\begin{array}{l}\text { Validation } \\
\text { (other purpose) }\end{array}$ & \\
\hline $\begin{array}{l}\text { Gustafson L et al. 1985; } \\
1995\end{array}$ & 55 & $\begin{array}{l}\text { Confusion or } \\
\text { dementia }\end{array}$ & $67-92$ & $\begin{array}{l}\text { OBS scale construction, ACS: } \\
\text { evaluation of treatment }\end{array}$ & $\begin{array}{l}\text { OBS } 1^{1} \\
\text { OBS } 2^{2}\end{array}$ & $\begin{array}{l}\text { Factor analysis } \\
5 \text { psyc.geriatr. scales }\end{array}$ & $\begin{array}{l}\mathrm{DAT}^{11}, \mathrm{VD}^{12} \text { or } \\
\text { other type }\end{array}$ \\
\hline Berggren et al. 1987 & 57 & Hip fracture & $65-92$ & $\begin{array}{l}\text { Comparing incidence of ACS } \\
\text { between } 2 \text { groups }\end{array}$ & $\begin{array}{l}\text { OBS } 1^{3} \\
\text { OBS } 2^{4}\end{array}$ & -- & DSM-III \\
\hline $\begin{array}{l}\text { Gustafson Y et al. 1988; } \\
\text { 1991b }\end{array}$ & 111 & Hip fracture & $65-96$ & Estimation of ACS incidence & $\begin{array}{l}\text { OBS } 1^{3} \\
\text { OBS } 2^{4}\end{array}$ & -- & DSM-III \\
\hline $\begin{array}{l}\text { Brännström et al. 1989; } \\
1991\end{array}$ & 35 & Hip fracture & $61-88$ & $\begin{array}{l}\text { Identif. ADL-perf. and nursing } \\
\text { problems. ACS diagnose test }\end{array}$ & $\begin{array}{l}\text { OBS } 1^{3} \\
\text { OBS } 2^{4}\end{array}$ & (Katz ADL-index) & DSM-III \\
\hline Hallberg et al. 1990 & 74 & Dementia & $\begin{array}{l}\text { median: } \\
85\end{array}$ & $\begin{array}{l}\text { Identif. of functional impairment } \\
\text { behavioural disturbances }\end{array}$ & $\begin{array}{l}\text { OBS } 1^{1} \\
\text { OBS } 2^{2}\end{array}$ & $\begin{array}{l}\text { Factor analysis } \\
\text { (Katz ADL-index) }\end{array}$ & $\begin{array}{l}\text { DAT, VD or other } \\
\text { type }\end{array}$ \\
\hline Gustafson Y et al. 1991a & 103 & Hip fracture & $65-102$ & $\begin{array}{l}\text { Evaluation of intervention } \\
\text { program } r / t \text { ACS incidence }\end{array}$ & $\begin{array}{l}\text { OBS } 1^{3} \\
\text { OBS } 2^{4}\end{array}$ & -- & DSM-III \\
\hline Gustafson Y et al. 1991c & 155 & Stroke & $40-101$ & Estimation of ACS incidence & $\begin{array}{l}\text { OBS } 1^{1} \\
\text { OBS } 2^{2}\end{array}$ & $\left(\mathrm{MMSE}^{5}\right)$ & DSM-III-R \\
\hline Andersson et al. 1993 & 1 & Hip fracture & 86 & $\begin{array}{l}\text { Identif. and investigation of } \\
\text { developing ACS episodes }\end{array}$ & OBS $1^{3}$ & (Case study) & \\
\hline Gustafson Y et al. 1993 & 83 & Stroke & $44-89$ & $\begin{array}{l}\text { Investigating activity of HPA } \\
\text { axis } r / t \text { ACS }\end{array}$ & $\begin{array}{l}\text { OBS } 1^{1} \\
\text { OBS } 2^{2}\end{array}$ & (MMSE) & DSM-III-R \\
\hline Jensen et al. 1993 & 28 & Dementia & $66-89$ & $\begin{array}{l}\text { Evaluation of the OBS scale } \\
\text { comparing it with } 3 \text { scales }\end{array}$ & $\begin{array}{l}\text { OBS } 1^{1} \\
\text { OBS } 2^{2}\end{array}$ & $\begin{array}{l}\text { MMSE, } \mathrm{GBS}^{6}, \mathrm{GDS}^{7} \\
\text { Katz ADL-index }\end{array}$ & $\begin{array}{l}\text { DAT, VD, other } \\
\text { DSM-III-R }\end{array}$ \\
\hline Minthon et al. 1996 & $\begin{array}{l}34 \\
22\end{array}$ & Dementia & $\begin{array}{l}50-76 \\
35-75\end{array}$ & $\begin{array}{l}\text { Analyzing if CFS NPY-levels r/t } \\
\text { clinical emotional symptoms }\end{array}$ & $\begin{array}{l}\text { OBS } 1^{1} \\
\text { OBS } 2^{2}\end{array}$ & $\begin{array}{l}\text { OBS 2: factor } 1 \text { with } \\
\text { MMSE }\end{array}$ & $\begin{array}{l}\text { DAT (DSM-III-R) } \\
\text { and FTD }{ }^{13}\end{array}$ \\
\hline Nyberg et al. 1996 & 123 & Hip fracture & $65-94$ & $\begin{array}{l}\text { Analyzing falls mechanism } \\
\text { Screening for lucid/not lucid }\end{array}$ & OBS $1^{3}$ & -- & -- \\
\hline Elmståhl et al. 1997 & 105 & Dementia & $\begin{array}{l}\mathrm{m}: 83 \\
\pm 6.0\end{array}$ & $\begin{array}{l}\text { Studying design of group living } \\
\text { units } r / t \text { psychiatric symptoms }\end{array}$ & $\begin{array}{l}\text { OBS } 1^{1} \\
\text { OBS } 2^{2}\end{array}$ & $\begin{array}{l}\text { (MMSE, } \\
\text { Katz ADL-Index) }\end{array}$ & $\begin{array}{l}\text { DAT (DSM-III-R), } \\
\text { VD or other type }\end{array}$ \\
\hline $\begin{array}{l}\text { Sandberg et al. 1998; } \\
1999\end{array}$ & 717 & $\begin{array}{l}\text { Elderly (diff. } \\
\text { diagnosis) }\end{array}$ & $75-100$ & $\begin{array}{l}\text { Studying the prevalence of } \\
\text { psychiatric symptoms-/ profiles }\end{array}$ & $\begin{array}{l}\text { OBS } 1^{1} \\
\text { OBS } 2^{2}\end{array}$ & $\begin{array}{l}\text { Item Depressed mood } \\
\text { with } \mathrm{MADRS}^{8}, \mathrm{CGI}^{9}\end{array}$ & DSM-III-R \\
\hline Edberg et al. 1999 & 22 & Dementia & $83-91$ & $\begin{array}{l}\text { Evaluation of the effects of one } \\
\text { year intervention program. }\end{array}$ & $\begin{array}{l}\text { OBS } 1^{1} \\
\text { OBS } 2^{2}\end{array}$ & (MMSE) & $\begin{array}{l}\text { DAT, VD or other } \\
\text { type }\end{array}$ \\
\hline Edlund et al. 1999 & 54 & Hip fracture & $40-98$ & $\begin{array}{l}\text { ACS: incidence, predisp.factors, } \\
\text { clin.profile, consequences }\end{array}$ & $\begin{array}{l}\text { OBS } 1^{3} \\
\text { OBS } 2^{4}\end{array}$ & -- & DSM-III-R \\
\hline Lundström et al. 1999 & 49 & Hip fracture & $65-98$ & $\begin{array}{l}\text { Evaluation of intervention } \\
\text { program } r / t \text { ACS incidence }\end{array}$ & $\begin{array}{l}\text { OBS } 1^{3} \\
\text { OBS } 2^{4}\end{array}$ & -- & DSM-III-R \\
\hline Nilsson et al. 2000 & 29 & Dementia & $\begin{array}{l}\mathrm{m}: 78.9 \\
\pm 6.8\end{array}$ & $\begin{array}{l}\text { Investig. cobolamin deficienc } \mathrm{r} / \mathrm{t} \\
\text { clin. changes and brain function }\end{array}$ & $\begin{array}{l}\text { OBS } 1^{1} \\
\text { OBS } 2^{2}\end{array}$ & $\begin{array}{l}10 \text { patients tested } \\
\text { with } \mathrm{OBS}+(\mathrm{MMSE})\end{array}$ & $\begin{array}{l}\text { DAT, VD or } \\
\text { mixed; DSM-III-R }\end{array}$ \\
\hline Andersson et al .2001 & 457 & $\begin{array}{l}\text { Hip fracture } \\
\text { Cox/gonarthr. }\end{array}$ & $\geq 65$ & $\begin{array}{l}\text { Identif. and investigation of } \\
\text { developing ACS episodes }\end{array}$ & OBS $1^{3}$ & $\begin{array}{l}\text { OBS } 1 \text { score with } \\
\text { DSM-IV }\end{array}$ & DSM-IV \\
\hline Edlund et al. 2001 & 101 & Hip fracture & $\geq 65$ & $\begin{array}{l}\text { Investig. of differences between } \\
\text { pre-, and postoperative ACS }\end{array}$ & $\begin{array}{l}\text { OBS } 1^{3} \\
\text { OBS } 2^{4}\end{array}$ & (MMSE) & DSM-IV \\
\hline Sandberg et al. 2001 & 133 & Stroke & $75-100$ & $\begin{array}{l}\text { Investigation of sleep apnea } r / t \\
\text { ACS, depressed mood, cognition }\end{array}$ & $\begin{array}{l}\text { OBS } 1^{1} \\
\text { OBS } 2^{2}\end{array}$ & $\begin{array}{l}\text { (MMSE, MADRS } \\
\text { BarthelADL-Index) }\end{array}$ & DSM-IV \\
\hline $\begin{array}{l}\text { Granberg-Axell et al. } \\
2001\end{array}$ & 31 & ICU patients & $23-85$ & $\begin{array}{l}\text { Investig. and describing ICU- } \\
\text { syndrome }\end{array}$ & OBS $1^{1}$ & -- & -- \\
\hline Eriksson et al. 2002 & 52 & $\begin{array}{l}\text { Coronary By- } \\
\text { pass patients }\end{array}$ & $\geq 60$ & $\begin{array}{l}\text { Investig. psychiatric patterns of } \\
\text { ACS after cardiac surgery }\end{array}$ & $\begin{array}{l}\text { OBS } 1^{1} \\
\text { OBS } 2^{2}\end{array}$ & $\mathrm{CAM}^{10}$ & DSM-IV \\
\hline Holmquist et al. 2003 & 175 & Elderly & $\mathrm{m}: 87$ & $\begin{array}{l}\text { Investig. prescript.of psychotrop. } \\
\text { drugs r/t living, psychiatr. diagn. }\end{array}$ & OBS 2 & (OBS 2: 17 items) & -- \\
\hline Lundström et al. 2003 & 78 & Hip fracture & $65-98$ & $\begin{array}{l}\text { Investig. of dementia incidence } \\
\text { and mortality rate } r / t \text { ACS }\end{array}$ & $\begin{array}{l}\text { OBS } 1^{3} \\
\text { OBS } 2^{4}\end{array}$ & MMSE & DSM-IV \\
\hline Lundström et al. 2005 & 400 & $\begin{array}{l}\text { General inter- } \\
\text { nal medicine }\end{array}$ & $\geq 70$ & $\begin{array}{l}\text { Investig. patient's outcome } \mathrm{r} / \mathrm{t} \\
\text { intervention program }\end{array}$ & OBS $2^{2}$ & $\begin{array}{l}\text { (MMSE) } \\
\text { (Katz ADL-index) }\end{array}$ & DSM-IV \\
\hline $\begin{array}{l}{ }^{1} \text { OBS } 1: 15 \text { or } 16 \text { items } \\
2 \text { OBS } 2: 39 \text { items } \\
{ }^{3} \text { OBS } 1 \text { modified: } 12 \text { iter } \\
{ }^{4} \text { OBS } 2 \text { modified: } 21 \text { iter }\end{array}$ & & $\begin{array}{ll}5 & \mathrm{M} \\
6 & \mathrm{G} \\
7 & \mathrm{G} \\
8 & \mathrm{M} \\
9 & \mathrm{C}\end{array}$ & $\begin{array}{l}\text { MSE: Mini } \\
\text { S: Gottfrie } \\
\text { S: Global } \\
\text { DRS Mon } \\
\text { I Clinical }\end{array}$ & $\begin{array}{l}\text { Mental StateExamination } \\
\text {;- Bråne-Steen scale } \\
\text { Detoriation scale } \\
\text { gomery-Åsberg Depression scale } \\
\text { Ilobal Impression scale }\end{array}$ & $\begin{array}{l}{ }^{10} \text { CAM } \\
{ }^{11} \text { DAT D } \\
{ }^{12} \text { VD V } \\
{ }^{13} \text { FTD F }\end{array}$ & $\begin{array}{l}\text { onfusion Assessment M } \\
\text { ementia of the Alzheime } \\
\text { scular dementia } \\
\text { ontotemporal dementia }\end{array}$ & $\begin{array}{l}\text { ethod } \\
\text { r type }\end{array}$ \\
\hline
\end{tabular}


Table 3. Two different factor analyses of the disorientation subscale, OBS 1

\begin{tabular}{|c|c|c|c|c|c|c|c|c|c|}
\hline \multicolumn{5}{|c|}{ Gustafson, L et al., $1985,1995^{1}$ ( $\left.n=55\right)$ (15 items) } & \multicolumn{5}{|c|}{ Hallberg et. al., 1990 ( $n=74)\left(16\right.$ items $\left.^{2}\right)$} \\
\hline Factor & Items & $\begin{array}{l}\text { Factor } \\
\text { loadings }^{3}\end{array}$ & $\begin{array}{l}\text { Eigen- } \\
\text { value }\end{array}$ & $\begin{array}{l}\text { Variance } \\
\%\end{array}$ & Factor & Items & $\begin{array}{l}\text { Factor } \\
\text { loadings }^{4}\end{array}$ & $\begin{array}{l}\text { Eigen- } \\
\text { value }\end{array}$ & $\begin{array}{l}\text { Variance } \\
\%\end{array}$ \\
\hline Time & 7 & $0.45-0.83$ & 3.5 & 23.3 & Time & 6 & - & 5.60 & 35.0 \\
\hline $\begin{array}{l}\text { Recent } \\
\text { memory }\end{array}$ & 6 & $0.46-0.87$ & 2.7 & 17.8 & $\begin{array}{l}\text { Past and } \\
\text { present events }\end{array}$ & 5 & - & 1.68 & 10.5 \\
\hline Identity & 5 & $0.40-0.73$ & 2.4 & 16.3 & Person & 5 & - & 2.51 & 15.7 \\
\hline $\begin{array}{l}\text { Cumulative } \\
\text { variance \% }\end{array}$ & & & & 57.5 & $\begin{array}{l}\text { Cumulative } \\
\text { variance \% }\end{array}$ & & & & 61.2 \\
\hline
\end{tabular}

${ }^{1}$ Factor analysis presented in Gustafson L et al., 1995.

2 Item "What is your name" is divided into two items: "What is your first name" and "What is your second name".

${ }^{3}$ Factor loadings above 0.40 are presented.

${ }^{4}$ Factor loadings are not presented. 
Table 4. Two different factor analyses of the confusion subscale, OBS 2

\begin{tabular}{|c|c|c|c|c|c|c|c|c|c|}
\hline \multicolumn{5}{|c|}{ Gustafson, L et al., 1985, $1995^{1}(n=55)\left(38\right.$ items $\left.^{2}\right)$} & \multicolumn{5}{|c|}{ Hallberg et. al., $1990(n=74)\left(37\right.$ items $\left.^{3}\right)$} \\
\hline Factor & Items & $\begin{array}{l}\text { Factor } \\
\text { loadings }^{4}\end{array}$ & $\begin{array}{l}\text { Eigen- } \\
\text { value }\end{array}$ & $\begin{array}{l}\text { Variance } \\
\%\end{array}$ & Factor & Items & $\begin{array}{l}\text { Factor } \\
\text { loadings }^{4}\end{array}$ & $\begin{array}{l}\text { Eigen- } \\
\text { value }\end{array}$ & $\begin{array}{l}\text { Variance } \\
\%\end{array}$ \\
\hline $\begin{array}{l}\text { Dyspraxia and } \\
\text { spatial } \\
\text { disorientation }\end{array}$ & 10 & $0.41-0.81$ & 6.8 & 17.9 & $\begin{array}{l}\text { Functional } \\
\text { perform., orien- } \\
\text { tation in ward }\end{array}$ & 9 & $0.44-0.92$ & 9.02 & 24.4 \\
\hline $\begin{array}{l}\text { Hallucinations- } \\
\text { syncope }\end{array}$ & 7 & $0.40-0.79$ & 3.6 & 9.5 & $\begin{array}{l}\text { Hallucinations, } \\
\text { illusions }\end{array}$ & 2 & $0.84-0.85$ & 1.68 & 4.5 \\
\hline Lack of vitality & 6 & $0.40-0.74$ & 3.4 & 8.9 & Mobility $^{5}$ & 9 & $-0.41,0.42-0.74$ & 2.04 & 5.5 \\
\hline Dysphasia & 5 & $0.44-0.72$ & 2.5 & 6.6 & $\begin{array}{l}\text { Speech perform., } \\
\text { psychomotor } \\
\text { slowing }\end{array}$ & 8 & $0.42-0.79$ & 3.34 & 9.0 \\
\hline Paranoia & 4 & $0.44-0.78$ & 2.1 & 5.5 & Hostility & 4 & $0.45-0.81$ & 1.98 & 5.4 \\
\hline Aggressiveness & 2 & $0.82-0.83$ & 1.8 & 4.7 & & & & & \\
\hline $\begin{array}{l}\text { Depression- } \\
\text { anxiousness }\end{array}$ & 5 & $-0.48,0.43-0.65$ & 1.7 & 4.5 & $\begin{array}{l}\text { Fluctuations in } \\
\text { mental state, } \\
\text { emotional }\end{array}$ & 7 & $0.55-0.84$ & 4.19 & 11.3 \\
\hline $\begin{array}{l}\text { Clinical } \\
\text { variations }\end{array}$ & 4 & $-0.44,0.48-0.74$ & 1.6 & 4.2 & disturbances & & & & \\
\hline Restlessness & 3 & $0.45-0.79$ & 1.5 & 3.9 & $\begin{array}{l}\text { Sensitivity and } \\
\text { euphoria }\end{array}$ & 4 & $0.43-0.65$ & 1.53 & 4.1 \\
\hline $\begin{array}{l}\text { Cumulative } \\
\text { variance } \%\end{array}$ & & & & 65.7 & $\begin{array}{l}\text { Cumulative } \\
\text { variance \% }\end{array}$ & & & & 63.6 \\
\hline
\end{tabular}

\footnotetext{
${ }^{1}$ Factor analysis presented in Gustafson et al., 1995.

2 Item "Epileptic seizures" excluded.

${ }^{3}$ Four items ("Perseverations", "Suspicious of relatives”, "Syncope”, ”Manages to recognize relatives”) are not presented in the original

article and two of these four items are not presented in the factor analysis, probably because the factor loadings were too small.

${ }^{4}$ Factor loadings above 0.40 are presented.

${ }^{5}$ lack of mobility, (Author's note).
} 
Table 5. Inter-rater reliability tests of the OBS Scale (OBS 1 and OBS 2) in elderly orthopedic and psychiatric patients

\begin{tabular}{|c|c|c|c|c|c|c|c|}
\hline \multirow[b]{2}{*}{ Reference } & \multirow[b]{2}{*}{$\begin{array}{l}\text { Cases } \\
(\mathrm{n})\end{array}$} & \multicolumn{2}{|c|}{ OBS 1} & \multicolumn{2}{|c|}{ OBS 2} & \multirow{2}{*}{$\begin{array}{l}\text { Patients } \\
\text { tested } \\
\text { times }\end{array}$} & \multirow{2}{*}{$\begin{array}{l}\text { Number } \\
\text { of raters }\end{array}$} \\
\hline & & $\begin{array}{c}\text { Inter-rater } \\
r_{s}^{1}\end{array}$ & $\begin{array}{c}\text { Identical } \\
\%\end{array}$ & $\begin{array}{c}\text { Inter-rater } \\
r_{s}^{1}\end{array}$ & $\begin{array}{c}\text { Identical } \\
\%\end{array}$ & & \\
\hline Berggren et al., $1987^{2}$ & 57 & & $>90$ & & $>90$ & $\geq 3$ & 2 \\
\hline Brännström et al., $1989^{2}$ & 35 & & $>95$ & & $>95$ & $\geq 7$ & 2 \\
\hline Edlund et al., $2001^{2}$ & 101 & & $>90$ & & $>90$ & 4 & $1-3$ \\
\hline Gustafson, L et al., 1985; 1995 & 55 & $0.71-1.0^{3}$ & $95 \pm 7$ & $0.61-1.0^{4}$ & $89 \pm 10$ & $\geq 5$ & 2 \\
\hline Gustafson, Y et al., $1988^{2}$ & 111 & & $>90$ & & $>90$ & $\geq 4$ & $1-3^{5,6}$ \\
\hline Gustafson Y et al., $1991 \mathrm{a}^{2}$ & 103 & & $>90$ & & $>90$ & $\geq 4$ & $1-3^{6}$ \\
\hline Hallberg et al., 1990 & 74 & $0.93-0.98$ & & $0.93-0.98$ & & $\geq 1$ & $3-4$ \\
\hline $\begin{array}{l}1 r_{s}=\text { Spearman rank correlation } \\
{ }^{2} \text { modified OBS scale } \\
{ }^{3} \text { mean } r_{s}: 0.92 \pm 0.1\end{array}$ & & & $\begin{array}{l}{ }^{4} \text { mea } \\
510 \mathrm{p} \\
698 \%\end{array}$ & $\begin{array}{l}0.90 \pm 0.11 \\
\text { nts rated by } \\
\text { rformed by } t\end{array}$ & $\begin{array}{l}\text { raters } \\
\text { e same rater }\end{array}$ & & \\
\hline
\end{tabular}

